\title{
Italy on COVID-19: Response and Strategy
}

\author{
Fadhila Inas Pratiwi \& Lilik Salamah
}

Universitas Airlangga

\begin{abstract}
Coronavirus Diseases (COVID-19) in Italy was remarkably immense, with more than two hundred thousand infected cases, and more than thirty thousand people had died because of the virus as of 27th July 2020. The high number of mortality rate makes the Italy case is essential to be further explored. This article aims to elaborate on government response and strategy in handling COVID-19 that spread within the country. This article unfolds in four sections; the first part discusses how COVID-19 could spread massively in Italy and cause death for a thousand people. The second part explains the government measure and its effectivity in containing the virus. The third part elaborates on the impact of COVID-19 along with the government response in the socioeconomic aspect. The last part explores the future of Italy after COVID-19. The article employs a literature review that analyzes information from various sources such as academic journals, research reports from the think tank, and news media outlets.
\end{abstract}

Keywords: Coronavirus, Italy, Government, Response

Kasus coronavirus di Italia sangat tinggi dan masif dengan lebih dari dua ratus ribu orang terinfeksi dan lebih dari lima puluh ribu orang meninggal per tanggal 27Juli 2020. Tingginya jumlah orang yang terinfeksi danjumlah orang yang meninggal membuat Italia menjadi kasus yang menarik untuk dibahas. Tujuan dari artikel ini untuk mengelaborasi tentang bagaimana respons dan strategi pemerintah Italia dalam menangani virus yang sudah menyebar di Italia. Artikel ini terdiri dari empat bahasan, pertama membahas tentang awal mula COVID-19 bisa menyebar secara masif di Italia dan mengakibatkan puluhan ribu orang meninggal. Kedua, membahas tentang bagaimana respons dari pemerintah Italia dan juga efektivitasnya dalam menangani penyebaran virus ini. Ketiga, membahas tentang dampak yang diakibatkan dari COVID-19 beserta respons pemerintah terhadap aspek sosio-ekonomi di Italia. Keempat, mendiskusikan bagaimana masa depan Italia setelah COVID-19. Artikel ini menggunakan tinjauan pustaka untuk melakukan analisis terkait dengan topik artikel yang berasal dari banyak sumber seperti jurnal akademis, laporan penelitian, artikel berita dan lain sebagainya.

Kata-kata Kunci: Coronavirus, Italia, Pemerintah, Respons 
As of $30^{\text {th }}$ July 2020, the COVID-19 in Italy already infected 246,488 people, and caused 35,123 people died (WHO 2020). Italy's first COVID-19 case was recorded on $21^{\text {st }}$ February 2020, when a 38-year-old man was brought to the hospital in Lodi, Northern Italy. At the same time, another case appears in Padua, Veneto region, which the first death coronavirus victim. The mortality rate in the Lombardy region is 10,022, much higher compared to China with 3,342 death tolls at that time. COVID-19 cases in Italy are the most horrendous event after World War II, where the mortality rate is higher than China as the origin place of the virus. Italy is the first European country to have a confirmed coronavirus case, which is soon spreading rapidly. Most of the people in Italy caught unprepared to face this virus, and health protection equipment such as masks insufficient for the people, particularly for the health workers. Furthermore, lack of ventilators and the high numbers of older people who are infected caused the death rate even much higher (Indolfi and Spaccarotella 2020). This article aims to explain the causes of the issues and how the Italian government responded, as well as unfolds the impact of those policies for Italy after this pandemic over.

\section{Italy Response and Strategy}

Besides the high number of older people, the culture in Italy makes COVID-19 spread quickly; for instance, Italians are used to get too close with other people. It is usual for them to have physical contact with other people, such as giving a hug and cheek-kiss among their family and friends. Besides, when they had a conversation with one another, there is no distance between one from another. Large social gatherings, particularly in the public area, become part of their daily life. Moreover, two-thirds of Italians live in a high-density urban area; Rome and Milan have 5,800 and 19,000 people per square mile. Those almost twice the density of Berlin and Washington D.C. Milan, in Northern Italy, as the state financial city has close relations with China, home for various multinational corporations. Many foreign workers who travel worldwide attend meetings and conventions in Northern Italy could spread the virus massively (Belligoni 2020). 
The northern regions of Lombardy, Veneto, and Emilia-Romagna have been most affected by the outbreak. Around 85\% confirm cases and place for $92 \%$ of death rates are from this region. However, the virus already spread in all 20 regions of the country silently. The virus spread undetected when the government already realize the situation, and the transmission has happened massively. The higher mortality rate because of the high number of older people, the average age people who died due to this virus is 81 . The government unprepared for this pandemic, although Italy becomes the first state that bans flights to and from China. However, people are traveling through connecting flight without stating where they come from (Godin 2020). This pandemic left Italy struggling to contain the virus.

As of $6^{\text {th }}$ March 2020, Italy became one of the worst-affected countries by COVID-19. Because of this virus, the government action is various, such as screening and suspending major community events, then closing educational institutions and hygiene/disinfection measures at the airports. On $8^{\text {th }}$ March, the government imposed a lockdown throughout the country to avoid COVID-19 spreading throughout the country. It makes Italy the first state that announced a national lockdown since the first COVID-19 outbreak in Wuhan. Furthermore, on 22 $^{\text {nd }}$ March, the government ordered the closure of all non-strategic businesses; only vital businesses such as supermarkets, pharmacies, banking services, and other public services such as transport remain active (Duddu 2020). Under lockdown measures, people could be fined for traveling within or outside the country without a permit. They could face up to three months in jail or should pay a \$234 fine. This measure received a positive response from WHO by saying that those rules served as courageous steps, and the government genuinely wants to stop the virus spread (Godin 2020). The Italian government was unprepared for the outbreaks since they are the first infected country in Europe. Italy's case offers the opportunity to analyze the missteps in managing this crisis.

The Italian government declared the emergency after the first two COVID-19 cases identified. On $22^{\text {nd }}$ February, the government enforced restrictions to contain the outbreak, included quarantine for over 50,000 people in 11 towns of northern Italy. Then in three 
weeks ( $21^{\text {st }}$ February $-11^{\text {th }}$ March), the virus has been infected 12,462 , and 827 people died during that time. The government representatives utter reassuring messages about government readiness in facing this challenge. Several government officials from various institutions deliver different focus in handling this crisis. For instance, the Minister of Health stated that the virus only infects people who have had direct contact with COVID-19 patients. Both Minister of Economy and Minister of Infrastructure and Transport said they would overcome the economic disturbance. On $25^{\text {th }}$ February, there was confusion between government institutions on how to respond COVID-19 crisis. Subsequently, it makes fake news easily penetrate, and the communications between government officials start to a rift. On $28^{\text {th }}$ February, for example, the government willing to provide economic assistance for the people in the affected area. However, in the other region, some schools start to reopen, and various public events attracting customers. In addition, on $2^{\text {nd }}$ March, the government makes three classifications of the region, whether they will implement lockdown measures. It consists of red (locked down), yellow (medium-high risk), and a low-risk zone. In the next eight days, on 10th March, it then changes into full lockdown in all regions (Ruiu 2020, 4-5).

According to McCann et al. (2020), the government instruction into total lockdown for the entire country three weeks after the first confirmed case was late. It shows that Italy underestimates the outbreak. In Northern Italy, where more cases have been reported, the closure of schools, museums, theatre, and public events' cancellation already occur. However, café and bars were still allowed to happen until 6 p.m. Milan cathedral also still open to receive the tourist while the cases continued to climb. On $8^{\text {th }}$ March, because of the high number of new infections, the government implemented lockdown measures in Northern Italy and limiting people's mobility. Unfortunately, the information leaked before the government lockdown, and people already leave the area. On $10^{\text {th }}$ March, Italy went under full lockdown, resulting in the slow infection rate, although the number of cases remains increasing. The scientist argues that Italian officials did not act decisively to stop the virus at the early stage. The officials underestimating the danger of the virus and miscalculate the spreading rate of the virus. The lockdown policy's consistency remains in place 
since the government already realizes its severity and extends the lockdown measure until mid-April. The consistency also receives public health expert's support. Because it is undoubtedly will slow the infection rate and capacity to prevent another immediate virus outbreak. The evidence also shows that Italy has been successful in flattening the curve within its borders. The proof is that the northern Italy region, such as Lodi and Padua, displays a significant decline of the new infection after the lockdown measure.

There are at least two explanations for Italy's late response and unpreparedness. The first reason is that Italy had no relevant experience in facing a public health crisis. The country was already in the complacent state and then caught in surprise as the pandemic continue damaging. Thus, the unpreparedness, late, slow, and then intense (panic) responses quickly are shown in Italy's case (Capano et al. 2020, 299). According to Gaub and Boswinkel (2020), experience does matter when it comes to public health crisis handling. Given examples such as Singapore and South Korea, which they experienced in handling SARS when facing COVID-19, they directly introduced large-scale measures before the first confirmed deaths. Therefore, it can be safely assumed that states with previous pandemic experience, the public, and the decision-makers had a higher level of awareness of protective measures regarding social distancing and handwashing procedures. They also conducted tests and tracking measures to their people. For example, Singapore even releasing a WhatsApp platform with frequent updates while Taiwan combined national healthcare and immigration database to send warning based on travelers' infection potential and activated the Central Epidemic Command Centre, created after the SARS epidemic.

The second reason refers to the government fragmentation in handling this crisis, leading to further confusion of the virus outbreak response. An effective lockdown measure needs early intervention, clear rules, and strict enforcement. These three elements did not exist in Italy. This pandemic turns as an opportunity for political parties to politicize the issue and degrading one another. The restrictive measure of lockdown becomes fragmented, adding that there are already competing situations between central-regional governments in Italy. The first lockdown 
was imposed in Lombardy and Veneto regions' cluster cities on $22^{\text {nd }}$ February, then on $8^{\text {th }}$ March, further lockdown throughout the Lombardy region and other 14 northern provinces. However, the lockdown was not obeyed in many cities in the northern region, and the residents could obtain "auto-certification" forms to let them travel in and out during the lockdown, such as for work, health, or "other necessities" which scope remain unclear. The lockdown with vague parameters leads to a conflict between Rome and the regional government. Then on $10^{\text {th }}$ March, the nationwide lockdown was imposed, and on $21^{\text {st }}$ March, the central government closed all non-essential businesses and industries and further restrictions on the people movement (Ren 2020, 5).

Italy's slow response shows that the country is experiencing a volatile political system and tense central-regional relations. Until its unification in 1861, Italy consists of independent city-states and republics. Regions have their power and resources, and they tend to ignore their president since the regional head should take responsibility for public health emergencies. Italy's volatile politics mostly shape lockdown implementation. Central-regional relations formed on fragile alliances of competitive political parties, accusing each other of a lack of response. The central government tried to scale up the responses, but the regional presidents rejected (Ren 2020, 7). Although the lockdown measure was late, the Italian government is capable of taking extreme restrictive measures, and the case of Italy is regarded as a reference model by other countries. At the beginning of the pandemic, the government left unprepared along with the Italian health system. Nonetheless, organizational and human factors are soon collaborating in facing this virus outbreak, which often occurs when there is an emergency in the public health situation (Fanelli et al. 2020, 2). Since the death number in Italy because of COVID-19 is exponentially higher than China, the political parties finally put aside their disagreement and managed to handle the crisis together (Ren 2020, 7-8). 


\section{Italy Lockdown Impact in Socio-Economic Aspect}

The lockdown policy in Italy works well in limiting people's movement. A research conducted by Pepe et al. (2020, 4-5) found that the outgoing and incoming traffic between all provinces decreases $40 \%$ on average during the total lockdown. The people who remain in their province is $54 \%$. The most substantial decrease is the travelers within Turin-Milan through a fast train line, it reduces between $50 \%$ until $80 \%$. This due to the work from the home policy adopted by many companies. Furthermore, the policy is successfully flattening the pandemic curve around the middle of March until the end of May. It also prepares Italy's health system to develop more preparation if there is a second wave of the outbreak (Capano 2020, 340).

Nevertheless, the lockdown policy comes with a price. According to Giuffrida (2020), lockdown has an impact on people's mental health. A recent survey suggests that eight from ten Italians confess that they need psychological support to overcome the pandemic. Since they are experiencing anxiety about the virus, the emotional impact of physical distancing, and the economic distress during this pandemic, psychologists argued that an increase in anxiety and depression is heavily related to the isolation measure. Italy also experiencing a financial recession, thus even makes people struggling to cope with financial difficulties. The threats are real, and they start to worry about how to fulfill their basic needs. While on the other hand, they are also facing job losses and worrying about how they could provide their children's needs. Since the beginning of March, 37 people have committed suicide, and 25 people attempted suicide. The economic struggle leads people to anxiety; only those who have a fixed income can endure the situation. While the others with low to no income and did not yet receive the government financial assistance as promised are experiencing higher distress.

The lockdown in Italy also affected small-medium enterprises (SMEs) variously since they have less resilience and flexibility on their operational costs. They also cannot survive longer compared to the larger companies, particularly after the government impose policies to close all non-essential or strategic production activities. Thus, resulted in a high unemployment rate, with approximately 
7.8 million workers become temporarily jobless. Moreover, regarding the education system, the closing of school since $5^{\text {th }}$ March resulted in the potential losses for the children learning, which correlated with human capital development. It is due to the fact that not every child could afford distance learning; $12,3 \%$ of children between 6 and 17 years old do not have a computer or tablet. Teachers in an impoverished region are only able to connect with $60 \%$ of their students. Because of the economic difficulties faced by their parents, 1.2 million minors are already living in poverty. The lockdown policy makes the children see and experiencing violence and abuse (Sanfelici 2020, 202-203). It is also predicted that Italy's GDP would be contracted by eight percent (while prior COVID-19, the GDP predicted to rise by o,6\%). Along with public debt to GDP rise significantly, before COVID-19, it was 135,2\%; after COVID-19, it reached $155,7 \%$, the unemployment rate reached $11,6 \%$. Furthermore, ten million Italians, a fifth of the total number of adults, will face poverty, unable to fulfill their basic needs such as food, medicines, and a place to live (Bull 2020).

State's response in facing the economic hardship for the population consists of providing 3.3 billion euros for resources distributed from the central government to regions. This funding is for the employees who do not receive any benefits and cover $80 \%$ of salary during lockdown measures. The recipient around three million people up to nine weeks. In addition to the SMEs, the government allocated 30 billion euros is for the affected company, including freelancers. The state guarantees those short-term funding (credits and loans) at favorable conditions, up to six years (Mascio et al. 2020, 4).

Furthermore, parents who have children under 12 years old were allowed to take leave for up to 15 days while receiving $50 \%$ of their salary. On $29^{\text {th }}$ March, the National Civil Protection sent 400 million euros to all municipalities for its population to buy food vouchers and basic food necessities based on population and income criteria. When it comes to mental health issues, the government also provides a toll-free number in order for the people to have psychological support during this crisis (Sanfelici 2020, 200-201). Italian Society for Emergency Psychology is taking part in helping people with psychology issues during the pandemic. It already 
helps 750 struggling residents with anxiety, loneliness, fear, panic attack. More psychologists also start to volunteer themselves in order to provide a free consultation (Perrone 2020).

It is also important to note the strength of Italian people solidarity when facing the pandemics. The lockdown makes people struggle more to get by each day. The citizen comes up with innovative efforts to support one another. The balcony conversations take place because of physical distancing. It is in Italian culture to meet with their friends, relatives, and colleague to meet in the early evening to have an aperitif, a glass of spritz or drinks in a coffee shop or bar before dinner, with a buffet of finger food. The aperitif was one of the first cultural losses of urban social life since lockdown occurs, and all coffee shops are close. This ritual is moving online, asking friends to meet online through share links, and having drinks and conversations. The people also moved their meeting from places at street level to balconies and windows, which act as a filter between the intimate spaces of isolation and the public space. Italian people also show an act of kindness by shouting positive and comforting sounds. For instance, they will clap together in honor of doctors and nurses, play some music, and sing the national anthem or simply sing a song (Tamborrino 2020; Thorpe 2020). Another example, in Naples, the solidarity taking the form of "solidarity baskets" to help feed the homeless. The baskets have a slogan "those who can: put something in; those who cannot: help yourself." The message triggered massive solidarity; people go out shopping and stop by the basket to put something inside, such as pasta, sugar, coffee, and cans of tuna (Poggioli 2020).

\section{The Future of Italy after COVID-19: Lessons Learned}

The state starts to prioritize the primary care sector spending through policy reforms and initiatives. A community-centered approach to health care was more developed than before, and health services turn out to have better performance in responding to the pandemic. Proactive tracking of the potential positive cases through home diagnosis and care is capable of decreasing the threat of COVID-19 spread within the hospital or other medical 
facilities that already happened in Lombardy, where the hospital becomes the center of testing that could make the situation worse. The collaboration between experts in various fields is expected to happen. In order for the government to cope with the crisis at the national and regional stage. It is because the impact of the crisis has various damage for people. For instance, children and young people do not know when they could go to school and interact with their friends. Thousands of children cannot afford online learning due to the digital divide. Elderly and people with disabilities also do not know when the social service could open and assist them, that their inability to access the facilities could even make the inequality higher. However, pandemic shows clearly the structural problem within the population. Many workers who are providing essential services are underpaid, and in some cases, they are irregular and exploited migrants. While the salary for football players is much higher than them, it is necessary to have market reorientation towards more sustainable (Sanfelici 2020, 204-205).

In responding to such situations, the regional government already conducted experiments towards a more inclusive approach. In Bologna and other cities, entrepreneurs, unions, and workers talking and negotiate how to restart the business safely. Various associations and movements are gaining more voice to raise awareness of the rights of vulnerable people. For instance, Forum Disuguaglianze e Diversità (Inequalities and Diversity Forum) work together with civil society organizations, trade unions, and researchers to find a solution to reduce inequalities. They arrange a proposal that provides public policies and collective actions that should be taken by the government at a national and local level (Sanfelici 2020, 205-206). Another solution in responding to the higher rate of unemployment is back to the agriculture sector. The industrialization after World War II makes Italy forgetting the past. However, this virus manages to change society and economic perspective towards agriculture. More Italians consider working as farmers since the needs to feed the country served as a top priority. Italy's agricultural minister argued that the virus makes us thinking about the model development changes. She said that agriculture could serve as a field that could bring a new generation a future. Since that, the virus has brought the country into food scarcity. Therefore, it is necessary to put the agriculture sector into 
attention. Italy's leading agricultural associations have established a vacancy website in the agricultural sector, and more than 20.000 people applied to the position, and most of them are Italians. This sector also receives support from the government thorough subsidy funding about more than a billion euros (Horowitz 2020). It is apparent that the government has serious intention in responding to the economic problem and can see another opportunity within the country, at least to reduce unemployment.

\section{Conclusion}

In responding to the COVID-19, Italy government is considered late and resulted in a massive death rate and infections within the country. There are two explanations about why it happened. First, Italy has no experience responding to the public health crisis and left them unprepared and even underestimating the virus spread. The second is that there is a strong sentiment between the regional and national levels of government, which could lead to confusion on how to respond the crisis-adding that the political parties using this opportunity to fight against their opponent. When the case increases significantly, the government officials start to work together and successfully implementing the lockdown. However, the lockdown measure applied gradually; nonetheless, the total lockdown can decrease the new infections rate and eventually flatten the curve. The government can also cope with the COVID-19 impact, such as mental health issues, by providing free psychological consultation and psychologists are willing to volunteer in providing free consultations. When it comes to economic hardship, the government provide funding assistance for SMEs, for parents who have children under 12 years old and cover $80 \%$ of the affected worker's salary. Society solidarity is also getting more prominent during this pandemic, and people supported each other in various ways. The last is that the government employs an inclusive method to respond the repercussion of COVID-19 for the Italian future, which is to reduce the inequality gap within the population and look for other opportunities such as the agricultural sector to bring more employment for the Italian people. 


\section{References}

\section{Journal and Online Journal}

Capano, Giliberto, et al., 2020. "Mobilising Policy (In)Capacity to Fight COVID-19: Understanding Variations in State Responses", Policy and Society, 39(3):285-308.

Capano, Giliberto, 2020. "Policy design and state capacity in the COVID-19 emergency in Italy: if you are not prepared for the (un)expected, you can be only what you already are", Policy and Society, 39(3):326-344.

Mascio, Fabrizio, et al., 2020. "Public Administration and Creeping Crises: Insights From COVID-19 Pandemic in Italy", The American Review of Public Administration, 50(6-7):621627.

Fanelli, Simone, et al., 2020. "Facing the Pandemic: The Italian Experience from Health Management Experts' Perspective", The American Review of Public Administration, 50(67):753-761.

Indolfi, Ciro and Carmen Spaccarotella, 2020. "The Outbreak of COVID-19 in Italy: Fighting the Pandemic", Journal of the American College of Cardiology, 2(9):1414-1418.

Ren, Xuefei, 2020. "Pandemic and lockdown: a territorial approach to COVID-19 in China, Italy and the United States", Eurasian Geography and Economics: 1-12.

Ruiu, Maria Laura,2020. "Mismanagement of Covid-19: lessons learned from Italy", Journal of Risk Research: 1-14.

Sanfelici, Mara, 2020. "The Italian Response to the COVID-19 Crisis: Lessons Learned and Future Direction in Social 
Development", The International Journal of Community and Social Development, 2(2): 191-210.

\section{Online Articles}

Belligoni, Sara, 2020. "5 reasons the coronavirus hit Italy so hard", The Conversation, 26 March, [online]. in https:// theconversation.com/5-reasons-the-coronavirus-hit-italyso-hard-134636 [Accessed 30 July 2020].

Bull, Martin J, 2020. "Coronavirus: lessons from Italy on the difficulties of exiting lockdown", The Conversation, 27 April, [online]. in https://theconversation.com/coronaviruslessons-from-italy-on-the-difficulties-of-exitinglockdown-137195 [Accessed 7 August 2020].

Duddu, Praveen, 2020. "Coronavirus in Italy: Outbreak, measures and impact" [online]. in https://www.pharmaceuticaltechnology.com/features/covid-19-italy-coronavirusdeaths-measures-airports-tourism/ [Accessed 4 August 2020].

Giuffrida, Angela, 2020. "Italy's lockdown has taken heavy toll on mental health, say psychologists", The Guardian, 21 May, [online]. in https://www.theguardian.com/world/2020/ may/21/italy-lockdown-mental-health-psychologistscoronavirus [Accessed 7 August 2020].

Godin, Melissa, 2020. "Why Is Italy's Coronavirus Outbreak So Bad?", Time, 10 March, [online]. in https://time. com/5799586/italy-coronavirus-outbreak/ [Accessed 4 August 2020].

Horowitz, Jason, 2020. "For Some Italians, the Future of Work Looks Like the Past", The New York Times, 24 May, [online]. in https://www.nytimes.com/2020/05/24/world/europe/ italy-farms-coronavirus.html [Accessed 8 August 2020].

McCann, Allison, et al., 2020. "Italy's Virus Shutdown Came Too Late. What Happens Now?", The New York Times, 5 April, [online]. in https://www.nytimes.com/ interactive/2020/04/05/world/europe/italy-coronaviruslockdown-reopen.html [Accessed 6 August 2020]. 
Perrone, Alessio, 2020. “'The Strength of Ordinary People.' The Creative Ways Italians Are Supporting Each Other During Their Coronavirus Lockdown", Time, 7 April, [online]. in https://time.com/5816650/italy-solidarity-coronavirus/ [Accessed 8 August 2020].

Poggioli, Sylvia, 2020. "In Naples, Pandemic' Solidarity Baskets' Help Feed The Homeless" [online]. in https://www. npr.org/2020/04/07/828021259/in-naples-pandemicsolidarity-baskets-help-feed-the-homeless [Accessed 8 August 2020].

Tamborrino, Rosa, 2020. “Here's how locking down Italy's urban spaces has changed daily life" [online]. in https://www. weforum.org/agenda/2020/o3/coronavirus-locked-downitaly-urban-space/ [Accessed 8 August 2020].

Thorpe, Vanessa, 2020. "Balcony singing in solidarity spreads across Italy during lockdown", The Guardian, 14 March, [online]. in https://www.theguardian.com/world/2020/ mar/14/solidarity-balcony-singing-spreads-across-italyduring-lockdown [Accessed 8 August 2020].

World Health Organization, 2020. "Italy" [online]. in https:// covid19.who.int/region/euro/country/it [Accessed 30 July 2020].

\section{Reports}

Gaub, Florence and Boswinkel, Lotje, 2020. WHO'S FIRST WINS? International crisis response to Covid-19. European Union Institute for Security Studies (EUISS).

Pepe, Emanuele, et al., 2020. COVID-19 outbreak response: a first assessment of mobility changes in Italy following national lockdown. medRxiv 